Roeland, Johan, Stef Aupers, Dick Houtman, Martijn de Koning and Ineke Noomen. "The Quest For Religious Purity In New Age, Evangelicalism And Islam Religious Renditions Of Dutch Youth And The Luckmann Legacy." Annual Review of the Sociology of Religion: Volume 1: Youth and Religion. Ed. G. Giordan. Brill, 2010, pp. 289-306

\title{
THE QUEST FOR RELIGIOUS PURITY IN NEW AGE, EVANGELICALISM AND ISLAM RELIGIOUS RENDITIONS OF DUTCH YOUTH AND THE LUCKMANN LEGACY
}

\author{
Johan Roeland, Stef Aupers, Dick Houtman, Martijn de Koning \\ and Ineke Noomen
}

\section{Introduction}

Even though it is beyond doubt that the once virtually omnipresent churched Christian religiosity has lost much of its former appeal in particularly the Northwestern-European countries (e.g., Norris and Inglehart, 2004), there are other and arguably more interesting stories to tell about the fate of religion in the West than that of its inevitable decline. These other stories address the changing shapes of religion among the remaining faithful, and the younger generations among them in particular (e.g., Achterberg et al., 2009).

To gain insight into religion's changing character in the contemporary West, this article discusses contemporary religious discourses and practices among youngsters in the Netherlands, where the Christian churches have lost even more of their former appeal and legitimacy than almost anywhere else in the Western world. Substantially, we address New Age spirituality, Evangelicalism and Islam, the three most popular, vital and visible strains of religion among contemporary Dutch youth. The three are nowadays not only embraced much more enthusiastically by the younger generations than any other type of religion, but moreover attain some striking features in their hands that serve to set them apart from the traditional types of church-based or mosque-based religion embraced by older generations of faithful.

Research has indicated that in the Netherlands and most other Western countries post-Christian spiritualities of life ('New Age') are more popular among the younger generations than among the elderly (Houtman and Aupers, 2007; Houtman and Mascini, 2002), while in Christian circles Evangelicalism is the single type of religion that today manages to arouse great enthusiasm among the young (Roeland, 2009). Although, needless to say, Evangelicalism is quite distinct from 
New Age spirituality and sets itself decidedly apart from it, we will see that there are nevertheless striking resemblances between the two that account for their popularity among the young. Likewise, the Islamic discourses and practices found among particularly Moroccan-Dutch youngsters, in particular those involved in Salafi networks, differ strikingly from these of their parents and equally strikingly resemble what we find among New Agers and Evangelicals.

From a theoretical point of view, the common features New Age, Evangelicalism, and Islam attain in the hands of contemporary Dutch youngsters highlight some major weaknesses in Thomas Luckmann's (1967) classical account of modern religion as radically privatized. This is not without significance, because his The Invisible Religion is arguably the most important book in sociology of religion since World War II and has shaped sociology of religion more than any other book during the last four decades.

Luckmann's main argument is that, although structural differentiation in modern society inevitably results in an erosion of the Christian monopoly, this does not simply mean the end of religion. Instead, he maintains, a 'market of ultimate significance' emerges, where religious consumers shop for strictly personal packages of meaning that remain without wider social and public significance. Ever since the appearance of Luckmann's book, accounts of modern religion as radically privatized, fragmented and socially and publicly insignificant have almost attained the status of sociological truisms. Modern religion has hence endlessly been understood as 'almost an exclusively psychological phenomenon, with very limited and indirect social consequence', as Besecke (2005: 187) rightly points out, adding that 'Luckmann's characterization of contemporary religion as privatized is pivotal in the sociology of religion; it has been picked up by just about everyone and challenged by almost no one' (Ibid.: 186). We demonstrate in this paper, however, that this is not at all what we find among young Dutch New Agers, Evangelicals and Muslims: their religion is neither ephemeral and superficial (section 2), nor socially unorganized (section 3), nor publicly insignificant (section 4).

Luckmann's book is hence just as much to be praised for its muchneeded widening of sociology of religion's scope beyond the study of firmly institutionalized Christian religion (Aupers and Houtman, 2009) as it is to be blamed for the relentless portrayal of modern religion as 'socially insignificant', 'uncommitted', and 'strictly personal'. Indeed, we will argue in this paper that the Luckmann legacy may have 
blinded sociologists of religion to processes of religious revitalization and rejuvenation that are taking place right before their eyes in Western countries like the Netherlands. Although, needless to say, much more research is needed to draw up a fair balance of the empirical correctness of the Luckmann legacy, we underscore that what follows is based on years of empirical research in each of the three religious subcultures in the Netherlands (e.g., Aupers, 2004; Aupers and Houtman, 2006; Bartels and De Koning, 2006; De Koning, 2008a; Houtman and Aupers, 2007; Houtman and Mascini, 2002; Noomen et al., 2006; Roeland, 2008, 2009).

\section{Religious Privatization or Religious Purification?}

\section{New Age Spirituality: 'Eternal Spiritual Wisdom'}

Ever since the appearance of Luckmann's book New Age spirituality has been understood as, the best example of a modern type of religion that constitutes nothing more than an incoherent collection of strictly personal spiritual ideas and practices. Participants in the spiritual milieu, it has been repeated again and again, tend to draw upon multiple traditions, styles and ideas simultaneously, combining these into idiosyncratic packages. New Age has thus been understood as a 'consumer religion par excellence' (Possamai, 2005: 49), 'pick-and-mix religion' (Hamilton, 2000), 'do-it-yourself religion' (Baerveldt, 1996) or a 'spiritual supermarket' (Lyon, 2000). Every single person in the spiritual milieu, Possamai maintains, constructs a 'subjective myth' and it is as if 'every human being should have his own paradigm' (2005: 57), while Steve Bruce (2002: 99) characterized New Age as a 'diffuse religion', noting that 'there is no (...) power in the cultic milieu to override individual preferences'.

These relentless portrayals of New Age spirituality as religiously incoherent blatantly miss the shared and undisputed discourse of 'self-spirituality' in the holistic milieu, a discourse that paradoxically demands and hence produces these omnipresent practices of individual bricolage. Ironically, then, these practices stem from a shared and morally binding religious discourse that insists that one should 'follow one's personal path' and 'listen to one's inner voice', rather than 'proving' its non-existence (Aupers and Houtman, 2006). This uncontested discourse of 'self-spirituality' postulates that the sacred cannot be found 'out there', like the transcendent personal God of Christianity 
or Islam, but rather 'in here' (Heelas and Houtman, 2009). In Heelas' (1996: 19) words: '[...] the most pervasive and significant aspect of the lingua franca of the New Age is that the person is, in essence, spiritual. To experience the 'Self itself is to experience 'God', 'the Goddess', the 'Source', 'Christ Consciousness', the 'inner child', the 'way of the heart', or, most simply and [...] most frequently, inner spirituality" (emphasis in original). Put crudely, then, New Agers believe that people do not have one, but two selves: they contrast a 'mundane', 'conventional', 'unnatural' or 'socialized' self, demonized as the 'false' or 'unreal' product of society and its institutions, with a 'higher', 'deeper', 'true', 'natural', 'authentic' or 'spiritual' self.

This spiritual self is conceived as laying hidden behind, beyond, or underneath the mundane self, residing in the deeper emotional layers of consciousness and understood as representing the person one 'really' or 'at deepest' is. It is believed to be intimately tied up with a universal power, life force or energy (mostly referred to as 'ki' or 'chi') that holistically permeates and connects 'all', that is, nature, society, and the cosmos. One's feelings, intuitions, and experiences are understood as emanations of this spiritual self, so that acting according to them is understood as connecting to this whole. According to New Agers, one should hence 'follow one's heart': do what 'feels good' and refrain from what 'feels bad'. 'The basic idea', again in Paul Heelas' words (1996: 23), 'is that what lies within-experienced by way of 'intuition', 'alignment' or an 'inner voice'-serves to inform the judgments, decisions and choices required for everyday life'. In New Age spirituality, in short, taking one's personal feelings and intuitions seriously is conceived as bringing life into line with who one 'essentially' or 'at deepest' is, and consequently as connecting to 'all that exists' (see also Hanegraaff, 1996).

This New Age discourse understands established religious traditions as flawed and alienating renditions of this eternal spiritual truth, because these have buried the latter under layers of dogma and doctrine, imposed upon the laity by powerful and dogmatic priesthoods. Religious traditions are as such not rejected tout court, but rather seen as placing too much emphasis on ritual conformity and institutional side issues, while 'deep down' they all refer to this same eternal and universal spiritual wisdom. In effect, New Age understands established religious traditions and institutions as alienating and misleading to the extent that they define themselves as conflicting with and superior to one another. They are seen as 'manmade' and hence 'artificial' and 
'inauthentic' corruptions that have subordinated the eternal spiritual wisdom to institutional interests (Hanegraaff 1996: 325). Practices of individual bricolage are hence rooted in the so-called philosophia perennis or 'perennial philosophy' that stems from Western esotericism and maintains that 'there are many paths, but just one truth'.

\section{Evangelicalism: 'Going One's Own Way with God'}

Something similar goes for Protestant Evangelicalism. The conviction that faith is primarily and eventually exclusively about the 'heart of the believer', i.e., about personal commitment rather than mere conformity to religious institutions, of course is and always has been a decisive feature of Protestantism. Although this emphasis on the heart of the believer has not prevented Protestantism from accepting all sorts of mediations between God and the individual, the consciousness and faith of the 'single individual' (Weber 2002[1930]: 60) and his or her immediate and unmediated relationship to God have always constituted Protestantism's single locus of practice and belief, in effect downplaying the relevance of supra-individual mediations and institutions (Keane, 2007). Evangelicalism, embraced enthusiastically by many young Dutch Protestants today, epitomizes and radicalizes this decisive feature of Protestantism (Roeland, 2009).

Contemporary Dutch Evangelicalism emphasizes the individual believer's personal relationship with God as the core of faith, not infrequently as a reaction to a firmly institutionalized Protestantism that is held to be too much preoccupied with the organization of the church or the righteousness of dogma. Much like New Agers, Evangelicals hence feature a Jamesian aversion to-or, at the very least, relativization of - the ecclesiastical organization of faith. 'It is all', to quote a respondent from Roeland's (2009) study of Evangelical youngsters in the Netherlands, 'about your personal life. It is not about the church you attend. It is all about your personal relationship with God. Your personal relationship with Jesus. Your personal relationship with the Holy Spirit.' This young man exemplifies the Evangelical conviction that church authorities and dogmas are subordinated to the individual believer's faith and his or her personal relationship with God. Faith is, to quote another respondent, primarily about 'going one's own way with God' and the compass to guide one on one's path is found in one's personal feelings and experiences rather than in the authority of the church and its religious doctrines. 
Contemporary Dutch Evangelicalism pushes the typically Protestant impetus towards the 'purification' of religion to its limits, spawning a radical religious individualism, i.e., an authentication of unmediated, experiential faith and a primacy of the epistemological principle of the authority of the self (Campbell, 2007: 344 ff; Van Harskamp, 2000; Versteeg, 2009). Given this emphasis on personal feelings and experiences it is hardly surprising that spokesmen (spokeswomen can hardly be found in these circles) of more traditional and conservative strains of churched Protestantism point out Evangelicalism's resemblance to the type of New Age spirituality discussed above. They observe that Evangelicalism, just like New Age, encourages practices of 'bricolage' and 'pick ' $n$ ' choose religion' and lament its detrimental consequences, particularly the erosion of church authority and dogma. The conservative Protestant theologian Horton, for instance, was quoted in the Dutch orthodox Protestant newspaper Het Reformatorisch Dagblad (January 9, 2008) as saying that he considered Evangelicals 'religious zappers', who 'compose their own religious cocktail, which is drenched by emotionalism'. Orthodox observers like Horton hence suggest that the Evangelical search for authentic and purified faith ends up in mere hyper-individual subjective preferences (Cotton, 1995), similar to the portrayal of New Age as radically fragmented and individualized in the sociological literature.

\section{A Quest for Pure Islam}

Contemporary renditions of Islam as found among Moroccan-Dutch youth feature a similar quest for religious purity beyond established Islamic traditions and institutions. Already from the 1990s onwards, researchers have witnessed an increasing salience of Muslim identity and Islam among Moroccan-Dutch youth (e.g., Bartelink, 1994; Buitelaar, 2002; Phalet, Lotringen, and Entzinger, 2000; Sunier, 1996), understood back then as an attempt to escape the impossible choice between 'being Moroccan' and 'being Dutch' (De Koning, 2008a; Entzinger and Dourleijn, 2006; Ketner, 2008). This strategy backfired however when after ' $9 / 11$ ' the focus of media and politics shifted to Islam and Muslims and their alleged lack of loyalty, and even threat, to Dutch society (Vliegenthart, 2007). Since then, Islam has increasingly been portrayed as prone to terrorism, intolerance, and oppression of women, and Moroccan-Dutch youth feel that they have come to be treated less willingly by the native Dutch. This situation only aggra- 
vated after Pim Fortuyn's election campaign and subsequent assassination in 2002; public statements by critics of Islam like Ayaan Hirsi Ali, Theo van Gogh, and Geert Wilders; the release of Hirsi Ali's anti-Islam movie Submission in 2004 and finally the murder of Van Gogh in that same year.

In short, Moroccan-Dutch youth have increasingly come to experience the Dutch Islam debate as a struggle against their religion, which forces them to once again make an impossible choice-this time between 'being Muslim' and 'being Dutch'. This has made them increasingly self-conscious about their religious identity and has drawn them into debates about 'what Islam really says' about, for instance, violent attacks against non-believers, homosexuality, the position of women, living as a Muslim in a non-Islamic country, and so on. In this context, the Islam of their parents has lost its 'self-evidence' and 'naturalness' and their own Islamic identities are increasingly actively constructed and negotiated. This applies to girls in particular, because much more than boys they find their behavior and attire scrutinized by other Dutch Moroccans and the native Dutch alike. They challenge the latter's stereotypes of 'oppressed Muslim women' and criticize the gender inequalities they experience in their relations with the former.

More than anything else, the increased salience of Islamic identities among Dutch Muslim youth has spawned a quest for 'real' or 'true' Islam, understood as more 'pure' than the compromised and particularistic Islam preached in most Dutch mosques. The latter is understood as diluting the message of 'true' Islam in such a way that it 'offends neither God nor the West', thus compromising 'true' Islam by selling out in exchange for financial subsidies or mere approval of the Dutch authorities. Differences between various strains of Islam in the Netherlands, a consequence of immigration from various Islamic countries (particularly Morocco and Turkey) and regions with distinct cultural and religious traditions, undermine the plausibility and legitimacy of each of these even further. If young Muslims find out from their classmates that, for instance, 'Moroccan Islam' differs in crucial ways from 'Turkish Islam', it becomes quite clear to them that these cannot both claim to represent 'true Islam'.

Precisely this awareness sparks a desire to separate truth from falsity that results in a process of religious 'purification' that is not unlike what we find among New Agers and Evangelicals. Because the established traditions and institutions are different among themselves, they come to be understood as shaped by historically grown traditions 
and/or (in the case of Islam) national cultures, and hence as 'false' and 'inauthentic'. In the case of Islam, this spawns strongly felt needs among Moroccan-Dutch youth to disentangle national culture and Islam, resulting in an ongoing purification of their cultural repertoires. Needless to say, this quest for 'pure' Islam is accompanied by major debates and conflicts about who interprets Islam 'correctly' and hence represents 'the truth'-particularly between youth on the one hand and their parents and, more generally, the older generation of Dutch Muslims, on the other (De Koning, 2008a).

This search for 'true' and 'pure' Islam is particularly salient among those who adhere to Salafism, an Islamic purification movement that has been active throughout the ages. It stresses the doctrine of the unity and uniqueness of God, or tawhid, as its main tenet and claims that the golden period of Islam ended after the first three generations of Muslims (around $810 \mathrm{AD}$ ), referred to as the 'pious forefathers' (al-salaf al-salih) (Meijer, 2009). The Salafi movement wants to revitalize Islam on the basis of an idealized and homogenized understanding of Islam as it existed in its early years, aiming to cleanse its contemporary manifestations from allegedly non-Islamic accretions like Sufism, Shi'a Islam, and local practices and doctrines held to have diluted and sullied its true message (Meijer, 2009). The Salafi movement is nowadays decidedly transnational, consists of local and global branches, and is characterized by a network structure. Although Salafi networks all share the doctrine of the unity and uniqueness of God, they differ widely in their strategies that may, depending on local circumstances, range from quietist to political and sometimes violent activities of da'wa-mission-and jihad (De Koning, 2009b).

Not unlike what we have seen for New Age and Evangelicalism, many elderly first-generation Dutch Muslims accuse their Salafist offspring of creating massively individualized renditions of Islam through copy-pasting texts from Islamic scholars and the Quran, and sometimes also secular political ideologies. They regard the resulting pastiches as outcomes of a fatal combination of all-too-easy Internet access (and hence access to a world of sources), ignorance about Islamic traditions, and emotional outrage about local and global Muslim predicaments. National Muslim organizations (Nederlandse Moslim Raad, 2007), intelligence and security services (AIVD, 2006) and researchers (Meijer, 2006) nonetheless understand these youthful practices of copy-pasting as creating a dangerously radicalized Islam. 
Although the quest for 'pure' Islam is not restricted to the Salafist movement, the latter has been the most successful in attracting Dutch Muslim youth, Moroccan-Dutch in particular. This is because the Salafist movement not only teaches its doctrines and practices, but also carves out a social space where Muslim youth can feel accepted and can express, nurture and enhance their faith (imaan), which is understood as being endangered by secular Western society. Participants of the movement typically conceive of their identities in terms of a conversion from 'sleeping Muslims' to 'returning to Islam', with Salafism offering the latter in its 'real', 'authentic', and 'unpolluted' form.

\section{Religious Purity beyond Traditions and Institutions}

Young New Agers, Evangelicals and Muslims all feature a critical stance $v i s-\grave{a}$-vis established religious traditions and institutions. They understand these as 'manmade' and hence 'artificial' and 'inauthentic' renditions of a 'pure' and 'eternal' religious or spiritual truth. New Agers embrace the perennialist understanding that all religious traditions are essentially perverted and distorted versions of the eternal spiritual wisdom that can be found within the self; young Evangelicals want to go beyond the church and its dogmas to establish a personal and unmediated relationship with God; young Salafist Muslims, finally, are critical of the culturalized religions of their parents and aim to return to 'pure' Islam.

It is clear that these religious purification processes do not entail the strictly personal, ephemeral, uncommitted, and superficial religiosities emphasized in the Luckmann legacy. They do, after all, not so much entail moves away from established religious traditions and institutions to less committing positions, but rather moves beyond these to more committing ones. They entail, in other words, a search for eternal and solidly grounded religious truths that lie beyond the flawed and particularistic institutions and traditions in the real world. This is not a postmodern flight to the surface (Jameson, 1991; Possamai, 2005), but a quest for 'solid', 'deep' and 'real' foundations in a world ruined by religious complacency and shiftlessness. 


\section{Sociality beyond Church and Mosque}

\section{Introduction}

The second major assumption of Luckmann's The Invisible Religion is that contemporary religion lacks social organization. The implicit point of reference here is, of course, the Christian church with its strong social grip on its members. After the loss of the Christian monopoly in the West, Luckmann maintains, institutionalized Christianity made way for an open spiritual marketplace in which individuals could seek for spiritual meaning. Just like Luckmann's assumption of contemporary religion as ephemeral and fragmented, this dichotomy between 'thick' and 'greedy' religious institutions that sustain social cohesion on the one hand and freely roaming and socially disembedded individuals on the other is also taken for granted in much of the literature.

\section{Networked Sociality}

Notwithstanding their aversion to particularistic religious traditions and 'thick' religious institutions, however, the spiritual and religious quests of young New Agers, Evangelicals and Muslims are certainly not socially detached ones. New Agers, for instance, relentlessly seek for spiritual inspiration at festivals that are the Dutch equivalents of better-known international ones like Body-Mind-Spirit (United Kingdom) or Burning Man (United States); they visit spiritual centers (Aupers, 2005), of which Glastonbury (Scotland) is the internationally best-known example; they participate in discussion groups about New Age bestsellers like The Celestine Prophecy or The Secret; and they participate in group trainings and courses where they intimately support one another and experience 'inner spirituality' in a, quite literally, collective embrace. In a similar vein, young Evangelicals visit musical events and large festivals in the Netherlands, where they sing, dance, praise the lord and experience 'togetherness', 'sociality' and 'collective effervescence' in a truly Durkheimian fashion. And although the search for 'pure' Islam leads young Muslims away from the mosques and imams of their parents, it simultaneously reunites them into all sorts of discussion groups, loosely-knit networks and online communities on the Internet, as well as in lecture circles and Islamic courses in people's homes (De Koning, 2008a, 2009b).

In contemporary Dutch religion we are hence not so much witnessing the withering away of the social, as the Luckmann legacy suggests, 
but rather the radical transformation of its organizational forms (cf. Maffesoli, 1996). Young New Agers, Evangelicals and Muslims are connected through and embedded in networked forms of sociality. They are all three particularly strongly present as virtual communities on the Internet and New Agers (neo-pagans in particular) were even among the 'first religious subcultures to colonize cyberspace' (Davis, 1998: 184). In these online communities they exchange information, shape and re-affirm their pagan identities and even perform collective online rituals (e.g., Noomen et al., 2006; Penzack, 2001; Radde-Antweiler, 2006). Some of them even consider the Internet their 'church-in lack of a better word' (Nightmare, 2001). Likewise, Evangelicals and Muslims (Becker, 2008; Benschop, 2005; De Koning, $2008 \mathrm{~b}$ ) use web forums and chat groups to exchange ideas, to 'bond' and 'bridge' and to express and re-affirm their religious identities.

The Internet provides young Dutch New Agers, Evangelicals and Muslims the opportunity to immerse themselves in social networks without losing their personal freedom, in short. As one of the pagan respondents of Macha Nightmare (2001: 65) notes: "If I want to learn about spirituality and have access to the Internet, I will be drawn to choose bits from a large number of sources, rather than taking all my information from one source. The resulting mix will be uniquely my own, rather than something dictated by an individual tradition." Online networked types of sociality hence do not entail the strict social obligations of traditional communities. They are of a more voluntary nature and people can easily join in and leave as they wish. It is up to individual believers to decide on the degree and nature of their engagement; one may stick to a particular chat room and become a loyal visitor, or may visit it only occasionally while surfing the web.

Although these 'light' organizational forms clearly differ markedly from firmly organized churches and mosques, it is equally clear that they contradict the notion that contemporary religion outside the boundaries of these established institutions entails nothing more than individuals who 'do their own thing' in splendid isolation of likeminded others (Besecke, 2005). These social forms are simply better adapted to these contemporary strains of religion, that all feature a marked aversion to established religious traditions and institutions. Even though Evangelicalism is often organized in churches besides the aforementioned types of organization, these are no longer (what Weber has called) 'hierocratic' organizations, i.e., bodies characterized by a top-down, hierarchical structure and governed by authoritative 
leaders with much power to control the community of believers. And even though the Salafi movement consists of several competing, and sometimes even plainly hostile, networks characterized by fission and fusion, each of these nonetheless features striking ideals of friendship, brotherhood and sisterhood (De Koning, 2009a). Contemporary quests for religious purity are, in short, no tragically isolated and privatized activities on a 'market of ultimate significance'.

The networked sociality that constitutes the major social shape of religion among Dutch religious youth is easily overlooked by sociologists of religion, because it transcends the dichotomy between 'thick' and 'greedy' religious institutions on the one hand and self-contained and socially disembedded individuals on the other-a dichotomy that is not only central to Luckmann's classical analysis, but also to much of classical and modern sociology in general (Maffesoli, 1996). We hence conclude with Besecke (2005) that beyond this increasingly inapplicable dichotomy, there are vibrant social conversations about religion and spirituality going on that need to be taken much more seriously than sociologists of religion have typically done in the past.

\section{Pure Religion's Social and Public Significance}

The third claim that undergirds Luckmann's privatization thesis is that modern religion remains firmly embedded in the private domain and hence lacks social and public significance (see also Bruce, 2002; Wilson, 1976). Again, this is not what we find among young Dutch New Agers, Evangelicals and Muslims. Although they no longer consider the demands made by particularistic religious traditions and their institutions legitimate, so that these have lost their ability to guide them in deciding the type of lives they need to live, this does not mean that religion tout court has lost its ability to do so. Indeed, for the new religious purists, the ethical demands made by 'pure' religion or spirituality have replaced these made by fossilized traditions and institutions, motivating them even more than the latter to live their lives according to these. Entailing a revitalization and rejuvenation of religion, religious purification hence endows religion with new and increased moral fervor.

This is even the case with New Age, allegedly the most privatized and least socially significant religion of the three cases under study (e.g., Bruce, 2002). The demand of being true to the inner self, of taking 
one's feelings, emotions, and intuitions seriously, means after all that basically everything - from sexuality to work-attains spiritual meaning and significance, making this type of religion even more difficult to expel from the public domain than traditional churched Christianity. "Indeed there would seem to be no activity, no matter how prosaic, whether it be gardening, flower arranging, or even shopping, that is not now being presented [...] as if it were also a spiritual exercise, something capable of leading to self-discovery and personal growth", Colin Campbell rightly notes (2007: 37$)$. The social and public significance of New Age spirituality that results from such an 'essentially spiritual approach to life' (Ibid.: 38 ) is particularly visible in the major role it has meanwhile come to play in the worlds of human resource management and business leadership (Aupers and Houtman, 2006; Costea et al., 2007).

The same goes for Evangelicalism: the experience of God's continuous presence in one's personal life spawns a strongly felt need to let Him guide one in all of one's life-in socializing with others, in selecting a spouse, in making choices in one's education or professional career, etcetera (Roeland, 2009). Much of Evangelicalism's increased visibility and vitality in the Dutch religious landscape takes the shape of a call for re-establishing religion as a moral resource for politics. Indeed, a recent analysis of Dutch survey data covering the period 1970-1996 demonstrates that while the number of Christians has declined steadily in this country, this process has coincided with a strengthening of the call for religious de-privatization and hence a larger role for religion in politics (Achterberg et al., 2009). Although it yet needs to be demonstrated that the latter trend is due to the Evangelicalism found among young Protestants, the latter are clearly much less likely than other and older Christians to accept the 'secularist truce'-the secularist contract that guarantees religious freedom, yet bans religion from the public sphere by relegating it to the private realm (see also Taylor, 2007).

The young generation of Moroccan-Dutch Muslims, finally, is also much more occupied with their religious identity than the older generations. Their quest for a purified Islam motivates them, too, to color more and more aspects of their private and public lives with their newly found pure Islam. It is a mere commonplace that Salafism in particular asserts the public relevance of 'true' Islam for law and politics in western societies. Although most Salafi networks were quietist until 2000, they meanwhile feature prominently in the media and in 
political debates about Islam and radicalization. While the ongoing Dutch Islam debate has almost by definition turned Islam into a public religion by making every single articulation of Islam a matter of public debate (Buijs, 2009; Buitelaar, 2008; De Koning, 2008a; Vliegenthart, 2007), the quest for 'pure' Islam in particular troubles opinion leaders who regard it as invariably radical, violent and intolerant (e.g., Hirsi Ali, 2007). As the principal targets of these critiques, Salafi organizations have been further stimulated to defend themselves against these charges by secular and anti-Islamic critics and to speak out for instance, about proposals to ban the face veil (niqab) or about Dutch foreign policies (De Koning, 2009b).

If we understand secularization in classical Weberian terms, i.e., as a decline of the influence of religious worldviews on social action (Chaves, 1994), we must conclude that the purification of religion invokes processes of de-secularization-processes that contradict the claim that contemporary religion remains firmly embedded in the private domain and lacks social and public significance. The purified religious worldviews of young Dutch New Agers, Evangelicals and Muslims are after all highly salient to them and as such motivate them to make major efforts to live their private and public lives accordingly. Religious purification, in short, works against religious privatization by spawning processes of de-secularization and de-privatization.

\section{Conclusion: In Search of Religious Purity}

After their path-breaking joint book The Social Construction of Reality (1966), Peter Berger and Thomas Luckmann went different ways in the sociological study of religion with The Sacred Canopy (Berger, 1967) and The Invisible Religion (Luckmann, 1967). While they agreed about the erosion of the Christian monopoly and the concomitant emergence of religious pluralism, they disagreed about the latter's implications for the future of religion. Berger heralded the coming of a secular age and Luckmann expected merely religious change. According to Berger, who assumed that the existence of competing or even incompatible religious truth claims would undermine the plausibility of each of the competitors, religious pluralism would result in secularization. According to Luckmann, as explained above, religion does not-and indeed cannot-disappear, though it does disappear from the public domain and become privatized. 
While our research among young Dutch New Agers, Evangelicals and Muslims confirms that firmly institutionalized particularistic religious traditions have become less plausible and legitimate, it also suggests that both Berger's and Luckmann's ideas about the consequences of this circumstance for the future of religion are flawed. Among religious Dutch youth, religious pluralism after all invokes neither radically privatized, ephemeral, uncommitted, and superficial religiosities (Luckmann), nor a full-out collapse of religious faith and a transition to secularism (Berger). Rather than a flight away from religious traditions and institutions towards either socially uncommitted 'consumer religions' (Luckmann) or a secularist outlook (Berger), we find zealous quests for 'real' and 'pure' religious truths that are solidly founded beyond the existing range of 'implausible' and 'inauthentic' religious traditions and institutions.

It is particularly striking to find that contemporary religious movements as far apart as New Age and Islamic Salafism have this hunt for 'real' or 'pure' religion in common. The two have after all often been portrayed as diametrically opposed extremes on a continuum ranging from respectively socially uncommitted relativism and individualism to blindly committed absolutism and collectivism (e.g., Bauman, 1997). And although there is no doubt that they are in many ways radically different, they are nonetheless basically identical in their understanding of historically grown and manmade religious traditions and institutions. They both conceive of the latter as degenerated, diluted and distorted renditions of the 'real' religious truth, which has become buried under institutional side issues, and hence as flawed, corrupted and perverted excuses for the original, imposed upon the laity by corrupted regimes and priesthoods that are more interested in power than in religious piety and purity.

Despite his classical analysis of the progressive disenchantment of the world, the resulting processes of religious purification in New Age, Evangelicalism and Islam alike are consistent with Max Weber's (1963[1922]) sociology of religion, in particular his ideas about 'cultural rationalization' (Campbell, 2007). Weber's sociology of religion after all assumes a universal human need of giving meaning to an essentially meaningless world and is hence based on a conception of culture as 'the endowment of a finite segment of the meaningless infinity of events in the world with meaning and significance from the standpoint of human beings' (Schroeder, quoted by Campbell 2007: 11). If religion loses its plausibility, it is hence not simply discarded, 
but a process of religious reconstruction is sparked so as to regain lost religious plausibility (Campbell, 2007). Such a process of 'rationalization' is precisely what we find in progress among young New Agers, Evangelicals and Muslims in the Netherlands. Exactly because today's religiously pluralist world embarrassingly exposes the particularisms of a wide range of Islamic, Christian and other religious traditions and institutions, these lose their binding power, as Berger (1967) and Luckmann (1967) were both right to emphasize. This does however not produce a turn away from religious committedness, but rather a zealous hunt for 'real' religious truth in New Age, Evangelicalism and Islam alike, whatever the further differences between the three may be.

\section{References}

Achterberg, P., D. Houtman, S. Aupers, W. de Koster, P. Mascini and J. van der Waal. 2009. A Christian Cancellation of the Secularist Truce? Waning Christian Religiosity and Waxing Religious Deprivatization in the West. Journal for the Scientific Study of Religion 48 (in press).

AIVD. 2006. Violent Jihad in the Netherlands: Current Trends in the Islamist Terrorist Threat. Den Haag: AIVD.

Aupers, S. 2004. In de ban van moderniteit: De sacralisering van het zelf en computertechnologie. Amsterdam: Aksant.

- 2005. 'We are all gods': New Age in the Netherlands (1960-2000). In The Dutch and their Gods. Secularization and Transformation of Religion in the Netherlands since 1950, ed. E. Sengers. Hilversum: Verloren, pp. 181-201.

Aupers, S. and D. Houtman. 2006. Beyond the Spiritual Supermarket: The Social and Public Significance of New Age Spirituality. Journal of Contemporary Religion 21, no. 2: pp. 201-222.

- 2009. Religion Beyond God: Relocating the Sacred to the Self and the Digital (submitted for publication).

Baerveldt, C. 1996. New Age-religiositeit als individueel constructieproces. In De kool en de geit in de nieuwe tijd: Wetenschappelijke reflecties op New Age, ed. M. Moerland. Utrecht: Jan van Arkel, pp. 19-31.

Bartelink, Y. 1994. Vrouwen over Islam: Geloofsvoorstellingen en -praktijken van Marokkaanse migrantes in Nederland (Brabant). Nijmegen: Katholieke Universiteit.

Bartels, E. and M. de Koning. 2006. For Allah and Myself: Religion and Moroccan Youth in The Netherlands. In Morocco and The Netherlands: Society, Economy, Culture, ed. P. Bos and W. Fritschy. Amsterdam: VU Publishers, pp. 146-156.

Bauman, Z. 1997. Postmodernity and Its Discontents. Cambridge, Oxford: Blackwell.

Becker, C. 2008. Terug naar de broncode: Salafistische internetforums in Nederland en Duitsland. ZemZem 4, no. 2: pp. 103-110.

Benschop, A. 2005. Kroniek van een aangekondigde politieke moord: Jihad in Nederland. Utrecht: Forum.

Berger, P. 1967. The Sacred Canopy: Elements of a Sociological Theory of Religion. Garden City, NY: Doubleday.

Berger, P. and Th. Luckmann. 1967. The Social Construction of Reality: A Treatise in the Sociology of Knowledge. Garden City, NY: Doubleday. 
Besecke, K. 2005. Seeing Invisible Religion: Religion as a Societal Conversation about Transcendent Meaning. Sociological Theory 23, no. 2: pp. 179-196.

Bruce, S. 2002. God is Dead: Secularisation in the West. Oxford: Blackwell.

Buitelaar, M. 2002. Negotiating the Rules of Chaste Behaviour: Re-Interpretations of the Symbolic Complex of Virginity by Young Women of Moroccan Descent in the Netherlands. Ethnic and Racial Studies 25, no. 3: pp. 462-489.

Buijs, F. 2009. Muslims in the Netherlands: Social and Political Developments after 9/11. Journal of Ethnic and Migration Studies 35, vol. 3: pp. 421-438.

Campbell, C. 2007. The Easternization of the West: A Thematic Account of Cultural Change in the Modern Era. Boulder, London: Paradigm.

Chaves, M. 1994. Secularization as Declining Religious Authority. Social Forces 72, no. 3: pp. 749-774.

Costea, B., N. Crump and K. Amiridis. 2007. Managerialism and 'Infinite Human Resourcefulness': A Commentary on the 'Therapeutic Habitus', 'Derecognition of Finitude' and the Modern Sense of Self. Journal for Cultural Research 11, no. 3: 245-264.

Cotton, I. 1995. The Hallelujah Revolution: The Rise of the New Christians. London: Prometheus.

Davis, E. 1998. TechGnosis: Myth, Magic and Mysticism in the Age of Information. London: Serpent's Tail.

De Koning, M. 2008a. Zoeken naar een 'zuivere' Islam: Geloofsbeleving en identiteitsvorming van jonge Marokkaans-Nederlandse moslims. Amsterdam: Bert Bakker.

- 2008b. Identity in Transition: Connecting Online and Offline Internet Practices of Moroccan-Dutch Muslim Youth. London: London Metropolitan University-Institute for the Study of European Transformations (ISET) (http://www.londonmet.ac.uk/ londonmet/library/c52116_3.pdf).

- 2009a. Changing Worldviews and Friendship: An Exploration of the Life Stories of Two Female Salafists in the Netherlands. In Global Salafism: Islam's New Religious Movement, ed. R. Meijer. London: Hurst, pp. 372-392.

- 2009b. Understanding the 'Others': Salafi Politics in the Netherlands. In Whatever Happened to the Islamists? Salafis, Heavy Metal Muslims and the Lure of Consumerist Islam, ed. O. Roy and A. Boubekeur. London: Hurst.

Entzinger, H. and E. Dourleijn. 2008. De lat steeds hoger: De leefwereld van jongeren in een multi-etnische stad. Assen: Van Gorcum.

Hamilton, M. 2000. An Analysis of the Festival for Mind-Body-Spirit, London. In Beyond New Age. Exploring Alternative Spirituality, ed. S. Sutcliffe and M. Bowman. Edinburgh: Edinburgh University Press, pp. 188-200.

Hanegraaff, W. 1996. New Age Religion and Western Culture: Esotericism in the Mirror of Secular Thought. Leiden: Brill.

Heelas, P. 1996. The New Age Movement: The Celebration of the Self and the Sacralization of Modernity. Oxford: Blackwell.

Heelas, P. and D. Houtman. 2009. RAMP Findings and Making Sense of the 'God Within each Person, Rather than Out There'. Journal of Contemporary Religion 24, no. 1: pp. 83-98.

Hirsi Ali, A. 2007. Infidel. Detroit: Free Press.

Houtman, D. and S. Aupers. 2007. The Spiritual Turn and the Decline of Tradition: The Spread of Post-Christian Spirituality in Fourteen Western Countries (1981-2000). Journal for the Scientific Study of Religion 46, no. 3: pp. 305-320.

Houtman, D., and P. Mascini. 2002. Why do Churches Become Empty, While New Age Grows? Secularization and Religious Change in the Netherlands. Journal for the Scientific Study of Religion 41, no. 3: 455-473.

Jameson, F. 1991. Postmodernism, or, the Cultural Logic of Late Capitalism. Durham: Duke University Press.

Keane, W. 2007. Christian Moderns: Freedom and Fetish in the Mission Encounter. Berkeley, Los Angeles, London: University of California Press. 
Ketner, S. 2008. Marokkaanse wortels, Nederlandse grond: Exploratie, bindingen en identiteitsstrategieën van jongeren van Marokkaanse afkomst. Groningen: Rijksuniversiteit Groningen.

Luckmann, Th. 1967. The Invisible Religion: The Problem of Religion in Modern Society. New York [etc.]: MacMillan.

Lyon, D. 2000. Jesus in Disneyland: Religion in Postmodern Times. Oxford: Polity Press.

Maffesoli, M. 1996. The Time of the Tribes: The Decline of Individualism in Mass Society. London, Thousand Oaks, New Delhi: SAGE.

Meijer, R. 2009. Introduction. In Global Salafism: Islam's New Religious Movement, ed. R. Meijer. London: Hurst, pp. 1-32.

Meijer, W. 2006. Traditie en toekomst van het islamitisch onderwijs. Amsterdam: Bulaaq.

Nederlandse Moslim Raad, Meeting 2007, http://nmronline.nl/promo/Ontmoeting2007web.pdf (accessed December 1, 2008).

Nightmare, M. 2001. Witchcraft and the Web: Weaving Pagan Traditions Online. Toronto: ICW Press.

Noomen, I., S. Aupers and D. Houtman. 2006. Soul-Searching in Cyberspace: Christianity and New Age on the Internet. Kristu Jyoti Journal: Compendium of the Social Doctrine of the Church 22, no. 2: pp. 93-107.

Norris, P. and R. Inglehart. 2005. Sacred and Secular: Religion and Politics Worldwide. Cambridge [etc.]: Cambridge University Press.

Penczak, C. 2001. City Magick: Urban Rituals, Spells, and Shamanism. York Beach: Weiser Books.

Phalet, K., C. Lotringen and H. Entzinger. 2000. Islam in de multiculturele samenleving: Opvattingen van jongeren in Rotterdam. Utrecht: Ercomer, Universiteit Utrecht.

Possamai, A. 2005. Religion and Popular Culture: A Hyper-real Testament. Brussells: Peter Lang.

Radde-Antweiler, K. 2006. Rituals Online: Transferring and Designing Rituals. Online Heidelberg Journal of Religions on the Internet 2, no. 1: pp. 54-72.

Roeland, J. 2008. Acceptation religieuze du moi: l'identité chez les jeunes néoévangélistes. Social Compass 55, no. 1: pp. 33-43.

- 2009. Selfation: Dutch Evangelical Youth Between Subjectivization and Subjection (in press).

Sunier, T. 1996. Islam in beweging: Turkse jongeren en islamitische organisaties. Amsterdam: Het Spinhuis.

Taylor, Ch. 2007. A Secular Age. Cambridge, MA, London: Harvard University Press.

Van Harskamp, A. 2000. Het nieuw-religieuze verlangen. Kampen: Kok.

Versteeg, P. 2009. Draw Me Close: An Ethnography of Experience in a Dutch Charismatic Church. New York: Edwin Mellen Press (in press).

Vliegenthart, R. 2007. Framing Immigration and Integration: Facts, Parliament, Media and Anti-Immigrant Party Support in the Netherlands. Amsterdam: Vrije Universiteit Amsterdam.

Weber, M. 1963[1922]. The Sociology of Religion. Boston: Beacon Press.

- 2002[1930]. The Protestant Ethic and the Spirit of Capitalism. London and New York: Routledge.

Wilson, B. 1976. Contemporary Transformations of Religion. Oxford: Oxford University Press. 